\title{
Cementochronology - The Still Underestimated Old "New" Method for Age-At-Death Assessment
}

\author{
Stephan Naji and Katrin Koel-Abt* \\ Pentagon, Defense POW/MIA Accounting Agency, USA \\ Submission: July 20, 2017; Published: July 28, 2017 \\ *Corresponding author: Katrin Koel-Abt, Pentagon, Defense POW/MIA Accounting Agency, USA.
}

\section{Mini Review}

Accurate age-at-death assessment is still a major issue in establishing a biological profile for forensic settings and in archaeological (paleodemography and paleoepidemiology) contexts. Even if results of aging methods are satisfactory for growing sub adults, accuracy and reliability for aging adults are weak at best, especially for individuals over 50 years old $[1,2]$. The purpose of all age-at-death estimation methods is to explore potential biological indicators closely related to the actual "chronological" age. For adult age categories, all dental or skeletal methods are based on senescence phenomena. But these biological modifications of the human body are strongly dependent on and an adaption to multiple external variables, such as pathologies, physical activities or environmental exposures. For example, when assessed with conventional ageing methods an older individual in good physical health can seem much younger, as can a rather young adult easily be misinterpreted as an old(er) individual when the bones are in poor physical shape due to pathologies or "wear and tear" (e.g. due to extreme physical activity, as for example oftentimes noticed in competitive athletes or infantry soldiers). Consequently, no single biological indicator used for traditional aging methods in anthropology today has an acceptable accuracy for estimating individual age [3].

Only one method in anthropology truly allows for a direct observation of a skeletal tissue that does not remodel throughout life: cementochronology, a chronobiologic method based on the counting of dental acellular cementum growth increments. Chronobiology is the "discipline that measures and explores mechanisms of biological temporal structures and their relations to rhythmic manifestation of living matter" [4]. Chronobiology includes all fields addressing the study of growth markers observable within organisms, in other words, "all histomorphological markers created inside hard growing tissues, regardless of their structure or meaning [5]. Skeletochronology (a word coined by Castanet \& colleagues [6] is dedicated to growing markers inside skeletal structures of vertebrae such as bones, calcified cartilage and teeth [5].

Cementum is a growing dental tissue deposited regularly throughout life and generally referred to as "cementum annulations" or "incremental lines" in forensic studies [7-10]. The analysis of cementum lines or cementochronology is used to estimate individual age-at-death and seasonality-of-death, thus mainly in archaeological contexts, with a very promising accuracy of $\pm 1-3$ years from the actual chronological age of an individual [11-13]. Cementochronology was first implemented in the 1950's on marine mammals $[14,15]$ and then largely on ungulates $[16,17]$. The method was quickly adapted to zoo archaeological problems of seasonality and mobility $[18,19]$. Subsequently, the identification of annual layers of cementum (1 dark +1 light band = 1 year) and their use for age estimation in forensic dentistry was formally tested on known age cases in 1982 by Stott and colleagues who concluded that "This technique may be extremely valuable in forensic medicine, forensic dentistry, and anthropology". This pilot study was quickly followed by positive validation studies [20-23] as well as negative ones [2426]. Finally, the method was adapted for human archaeological remains [27] and most notably by Wittwer-Backofen and Buba [28] who then established the bases for the current protocols [11].

Overall, cementochronology has been successfully implemented on over 72 species of mammals across 21 families and 9 orders [17,29-31]. Cementochronology is one of the very few intensively test edaging methods in humans. It has been tested by 31 different laboratories in 11 countries on 4 continents on well over 2000 known-age human teeth (Table 1). In all cases, a circa-annual rhythm of a cellular cementum deposition has been observed as a pair of alternating translucent and opaque increments, interpreted as a two-phase annual 
growth process in transmitted bright light microscopy. No other estimator in anthropology has been independently validated at this scale. Therefore, we can logically ask why this method is still not a standard method more widely used in forensic or bioarchaeological contexts?

Table 1: Overview Validation Studies on Cementochronology.

\begin{tabular}{|c|c|c|}
\hline Country & Year & Sources \\
\hline Austria & 2008 & Meinl et al. [42] \\
\hline Brazil & 1999 & Sousa et al. [43] \\
\hline Brazil & 2010 & Dias et al. [44] \\
\hline Egypt & 2015 & Alghonamy et al. [45] \\
\hline France & 2006 & Blondiaux et al. [46] \\
\hline France & 2017 & Bertrand et al. [47] \\
\hline France & 2016 & Lanteri et al. [48] \\
\hline France & 2016 & de Broucker et al. [49] \\
\hline Germany & 2001 & Kagerer, Grupe [50] \\
\hline Germany & 2004 & Wittwer-Backofen et al. [51] \\
\hline Germany & 2004 & Pilloud [52] \\
\hline Germany & 2009 & Obertova et Francken [53] \\
\hline India & 2008 & Aggarwal et al. [54] \\
\hline India & 2010 & Kassetty et al. [55] \\
\hline India & 2015 & Shruthi et al. [56] \\
\hline India & 2015 & Padavala and Gheena [57] \\
\hline India & 2014 & Gupta et al. [58] \\
\hline India & 2009 & Pundir et al. [59] \\
\hline India & 2009 & Avadhani et al. [60] \\
\hline India & 2010 & Joshi et al. [61] \\
\hline Italy & 2007 & Pinchi et al. [62] \\
\hline Lithuania & 2001 & Jankauskas et al. [63] \\
\hline Lithuania & 2003 & Bojarun et al. [64] \\
\hline Norway & 1995 & Kvaal et Solheim [65] \\
\hline Singapore & 1986 & Lucas and Loh [66] \\
\hline USA & 1982 & Stott et al. [67] \\
\hline USA & 1986 & Condon et al. [68] \\
\hline USA & 1986 & Lipsinic et al. [69] [70] \\
\hline USA & 1988 & Miller eoran [71] \\
\hline
\end{tabular}

There are a certain number of basic obstacles, technical and theoretical, preventing a wider implementation of cementochronology.

a) First, cementochronology is a histologic technique, which is generally not very appealing to most "anthropology users" who are often not familiar with this type of section preparation. Besides the initial and somewhat cost-intensive laboratory set up, the learning curve of properly and routinely using the method is rather long. The user must also be well- trained in reading and understanding dental histological features and thus be familiar with cementum biology. However, forensic anthropology is done within a forensic sciences laboratory which always includes a histology lab that routinely does histological analyses of soft tissues for pathological purposes. It would be quite simple to set up the labto include standard dental histology procedures to implement cementum analysis.

b) Second, the counting procedure of cementum lines is a strong impediment because of its apparent subjectivity and potential inter-observer errors. Yet with proper training, removing intra-observer variation is rather easy and reducing inter-observer error is definitely possible.

c) Third, cementochronology is a destructive technique. However, only the root is involved and cheap micro CT scanning options are available to make a permanent virtual record of the root's morphology and structure.

d) Fourth, there are still no answers to the question of what the etiology of cementum is and why cementum increments are semiannually deposited. As of today, there are no satisfying answers to these questions, although extensive research has been conducted [32-34]. Nonetheless, empirical evidence on over 70 mammal species has demonstrated that a cellular cementum growth is seasonal. Not understanding the detailed mechanism of a biological process should not be a deterrent to using it. Many other biological processes cannot be completely explained yet either. What for example are the exact biomechanical rules behind ageing of the pubic symphysis, or behind dentine transparency? None of these mechanisms can be fully explained, yet they are routinely part of standard operating procedures in forensic contexts, despite the fact that only very few validation studies exist and that they have all demonstrated a very weak correlation with chronological age at best [35].

e) Last but not least, what is the nature of the lines we are counting? Recent advances in cementum studies seem to favor the differential mineralization hypothesis over the collagen fiber orientation one [36-38].

Regardless of the nature of these layers, we know how to systematically visualize a cellular cementum increments through proper thin-section preparation $[37,39,40]$. Not only does empirical evidence allow us to estimate age-at-death, we can also estimate the season-at-death from the last forming increment $[9,27,41]$. With the increasing number of validation studies on several mammals, the volume of empirical evidence confirming the periodicity of cementum growth is overwhelming and use of the technique should be encouraged as a highly efficient aging tool.

\section{Acknowledgement}

This work was supported in part by the "Agence National de la Recherche" [project CemeNTAA, ANR-14-CE31-0011], and in 
part by an appointment to the Research Participation Program for the Defense POW/MIA Accounting Agency, administered by the Oak Ridge Institute for Science and Education through an agreement between the U.S. Department of Energy and Defense POW/MIA Accounting Agency. The opinions or assertions contained herein are the private ones of the author(s) and are not to be construed as official or reflecting the view of the DoD.

\section{References}

1. Bocquet Appel JP, Masset C (1982) Farewell to pale demography. Journal of Human Evolution p. 1-13.

2. Séguy I, Buchet L (2013) Definition and Exploration of a Pre-industrial Standard. In: Handbook of Palaeodemography. INED Population Studies. Springer International Publishing. pp. 143-162.

3. Kemkes-Grottenthaler A (2002) Aging through the ages: historical perspectives on age indicator methods. In: Hoppa RD, Vaupel JW, (eds.), Paleodemography: age distributions from skeletal samples. Cambridge: Cambridge University Press p. 48-72.

4. Cugini P (1993) Chronobiology: principles and methods. Ann Ist Super Sanita 29(4): 483-500.

5. Baglinière JL, Castanet J, Conand F, Meunier FJ (1992) Terminologie en sclérochronologie chez les Vertébrés. In: Baglinière J-L, Castanet J, Conand F, Meunier FJ, (Eds.), Tissus durs et âge individuel des vertébrés. ORSTOM-INRA. Paris, pp. 443-447

6. Castanet J, Meunier FJ, Ricqlès A de (1977) L'enregistrement de la croissance cyclique par le tissu osseux chez les vertébrés poïkilothermes: données comparatives et essai de synthèse. Bull Bio Fr Belg 111: 183-202.

7. Stott GG, Sis RF, Levy BM (1982) Cemental Annulation as an Age Criterion in Forensic Dentistry. Journal of Dental Research 61(6): 814817.

8. Maat GJR, Gerretsen RRR, Aarents MJ (2006) Improving the visibility of tooth cementum annulations by adjustment of the cutting angle of microscopic sections. Forensic Science International 159(Supplement: 1: 1: S95-S99.

9. Wedel VL (2007) Determination of Season at Death Using Dental Cementum Increment Analysis. Journal of Forensic Sciences 52(2): 1334-1337.

10. Naji S, Colard T, Blondiaux J, Bertrand B, d'Incau E, et al. (2016) Cementochronology, to cut or not to cut? International Journal of Paleopathology 15: 113-119.

11. Wittwer-Backofen U, Gampe J, Vaupel JW (2004) Tooth cementum annulation for age estimation: Results from a large known-age validation study. American Journal of Physical Anthropology 123: 119129.

12. Dias PEM, Beaini TL, Melani RFH (2010) Age estimation from dental cementum incremental lines and periodontal disease. Journal of Forensic Odontostomatology 28(1): 13-21.

13. Koel-Abt K, Wilson N, Schmidt K (2017) Development of Dental Cementum Increment Analysis for Age at Death Determination within the Identification Process of Unaccounted-for US Service Members. In: 86th American Association of Physical Anthropology annual meeting. Vol. 182 S64. New Orleans (LA): Wiley Liss, USA, pp. 250.

14. Scheffer VB (1950) Growth layer on the teeth of Pinnipedia as an indication of age. Science 112(2907): 309-311.

15. Laws RM (1952) A New Method of Age Determination for Mammals. Nature 169(4310): 972-973
16. Sergeant DE, Pimlott DH (1959) Age determination in moose from sectioned incisor teeth. Journal of Wildlife Management 23: 315-321.

17. Klevezal GA, Kleinenberg SE (1969) Age determination of mammals from annual layers in teeth and bones. Israel Program for Scientific Translations (Ed. orig.: Opredelenie Vozrasta mlekopitayushchikh po sloistym strukturam zubov i kosti. Moskva: Institut Morfologii Zhivotnykh im. AN Severtsova, Akademiya Nauk SSSR, Russia.

18. Saxon A, Higham C (1968) Identification and interpretation of growth rings in the secondary dental cementum of Ovis aries. Nature 219: 634-635.

19. Savelle J, Beattie OW (1983) Analysis of dental annuli in Muskoxen (Ovibos moschatus) as an aid to the determination of archaeological site seasonality. Revue Canadienne d'Anthropologie 3:123-129.

20. Naylor JW, Miller WG, Stokes GN, Stow GG (1985) Cemental Annulation Enhancement: A Technique for Age Determination in Man. American Journal of Physical Anthropology 68(2): 197-200.

21. Condon K, Charles DK, Cheverud JM, Buikstra JE (1986) Cementum annulation and age determination in Homo sapiens. II. Estimates and accuracy. American Journal of Physical Anthropology 71(3): 321-330.

22. Lipsinic FE, Paunovich DG, Houston DG, Robinson SF (1986) Correlation of age and incremental lines in the cementum of human teeth. Journal of Forensic Sciences 31(3): 982-989.

23. Kvaal SI, Solheim $T$ (1995) Incremental lines in human dental cementum in relation to age. Eur J Oral Sci 103(4): 225-230.

24. Lucas PW, Loh HS (1986) Are the incremental lines in human cementum laid down annually? Ann Acad Med Singap 15(3): 384-386.

25. Miller CF, Dove SB, Cottone JA (1988) Failure of use of cemental annulations in teeth to determine the age of humans. Journal of Forensic Sciences 33(1): 137-143.

26. Solheim T (1990) Dental cementum apposition as an indicator of age. Scand J Dent Res 98(6): 510-5199.

27. Klevezal GA, Shishlina NI (2001) Assessment of the Season of Death of Ancient Human from Cementum Annual Layers. Journal of Archaeological Science 28: 481-486.

28. Wittwer-Backofen U, Buba H (2002) Age estimation by tooth cementum annulation: perspective of a new validation study. In: Hoppa RD, Vaupel JW, (eds.), Paleodemography, age distributions from skeletal samples. Cambridge: Cambridge University Press, England, UK, pp. 107-128.

29. Grue H, Jensen B (1979) Review of the Formation of Incremental Lines in Tooth Cementum of Terrestrial Mammals. Danish Review of Game Biology 11: 1-48.

30. Stallibrass S (1982) The use of cement layers for absolute ageing of mammalian teeth: a selective review of the literature, with suggestions for further studies and alternative applications. In: Wilson B, Grigson C, Payne S (eds.), Ageing and Sexing Animal Bones from Archaeological Sites. BAR International Series 109, Oxford: British Archaeological Report, England, UK, pp. 109-126.

31. Klevezal GA (1996) Recording Structures of Mammals: Determination of Age and Reconstruction of Life History. Rotterdam: A A Balkema Series, Netherlands.

32. Bosshardt D, Luder HU, Schroeder HE (1989) Rate and growth pattern of cementum apposition as compared to dentine and root formation in a fluorochrome-labelled monkey (Macaca fascicularis). Journal de biologie buccale 17(1): 3-13.

33. Foster BL, Ao M, Willoughby C, Soenjaya Y, Holm E, et al. (2015) Mineralization defects in cementum and craniofacial bone from loss of bone sialoprotein. Bone 78: 150-164. 
34. Yamamoto T, Hasegawa T, Yamamoto T, Hongo $\mathrm{H}$, Amizuka N (2016) Histology of human cementum: Its structure, function, and development. Japanese Dental Science Review 98(2): 102-109.

35. Garvin HM, Passalacqua NV (2012) Current Practices by Forensic Anthropologists in Adult Skeletal Age Estimation. Journal of Forensic Sciences 57(2): 427-433.

36. Colard T, Falgayrac G, Bertrand B, Naji S, Devos O, et al. (2016) New Insights on the Composition and the Structure of the Acellular Extrinsic Fiber Cementum by Raman Analysis. PLOS ONE 11: e0167316.

37. Naji S, Rendu W, Gourichon L, Cai Z, Stock SR (2017) Cementum ultrastructure, a comparative perspective from synchrotron x-ray scanning: fluorescence and diffraction. In: 86th American Association of Physical Anthropology annual meeting. Vol. 182 S64. New Orleans (LA): Wiley Liss, USA. pp. 296.

38. Stock SR, Finney LA, Telser A, Maxey E, Vogt S, et al. (2017) Cementum structure in Beluga whale teeth. Acta Biomaterialia 48: 289-299.

39. Wittwer-Backofen U (2012) Age Estimation Using Tooth Cementum Annulation. In: Bell LS (eds.), Forensic Microscopy for Skeletal Tissues: Humana Press, New York, USA, pp. 129-143.

40. Colard T, Bertrand B, Naji S, Delannoy Y, Bécart A (2015) Toward the adoption of cementochronology in forensic context. Int J Legal Med 129: 1-8.

41. Wedel VL, Wescott DJ (2016) Using dental cementum increment analysis to estimate age and season of death in African Americans from an historical cemetery in Missouri. International Journal of Paleopathology 15: 134-139.

42. Meinl A, Huber CD, Tangl S, Gruber GM, Teschler-Nicola M, et al. (2008) Comparison of the validity of three dental methods for the estimation of age at death. Forensic Science International 178(2-3): 96-105.

43. Sousa EM, Stott GG, Alves JB (1999) Determination of age from cemental incremental lines for forensic dentistry. BiotechHistochem 74(4): 185-193.

44. Dias PEM, Beaini TL, Melani RFH (2010) Age estimation from dental cementum incremental lines and periodontal disease. Journal of Forensic Odontostomatology 28(1): 13-21.

45. Alghonamy WY, Gaballah OM, Labah DA (2015) Age estimation in adult human sound and periodontally affected teeth using tooth cementum annulations. Tanta Dental Journal 12: 277-285.

46. Blondiaux J, Gabart N, Alduc-Le Bagousse A, Niel C, Tyler E (2006) Relevance of Cement Annulations to Paleopathology. Paleopathology Newsletter p. 4-13.

47. Bertrand B, Colard T, Ramos Magalhaes J, Cunha E, Hedouin V (2017) Computerized Cementochronology Taking the 16-bit between the teeth. American Journal of Physical Anthropology S.64, 120.

48. Lanteri L, Recrutement, paléodémographie et cémentochronologie. Application à un contexte d'inhumation paroissial d'Ancien Régime : Notre-Dame du Bourg à Digne-les-Bains. (Aix-Marseille, 2016).

49. Broucker Ade, Colard T, Penel G, Blondiaux J, Naji, S (2016) The impact of periodontal disease on cementochronology age estimation. International Journal of Paleopathology 15: 128-133.

50. Kagerer P, Grupe G (2001) Age-at-death diagnosis and determination of life-history parameters by incremental lines in human dental cementum as an identification aid. Forensic science international 118(1): 75-82.

51. Wittwer-Backofen U, Gampe J, Vaupel JW (2004) Tooth cementum annulation for age estimation: Results from a large known-age validation study. American Journal of Physical Anthropology 123: 119129
52. Pilloud S (2004) Can there be age determination on the basis of the dental cementum also in older individuals as a significant context between histological and real age determination. AnthropologischerAnzeiger 62: 231-239.

53. Obertova Z, Francken M (2009) Tooth cementum annulation method: accuracy and applicability. Front Oral Biol 13: 184-189.

54. Aggarwal P, Saxena S, Bansal P (2008) Incremental lines in root cementum of human teeth: an approach to their role in age estimation using polarizing microscopy. Indian J Dent Res 19: 326-330.

55. Kasetty S, Rammanohar M Raju Ragavendra T (2010) Dental Cementum in Age Estimation: A Polarized Light and Stereomicroscopic Study. Journal of Forensic Sciences 55(3): 779-783.

56. Shruthi BS, Donoghue M, Selvamani M, Kumar PV (2015) Comparison of the validity of two dental age estimation methods: A study on South Indian population. J Forensic Dent Sci 7(3): 189-94.

57. Padavala S, Gheena S (2015) Estimation of Age Using Cementum Annulations. J Pharm Sci \&Res 7(2): 461-463.

58. Gupta P (2014) Human Age Estimation From Tooth Cementum and Dentin. Journal of Clinical and Diagnostic Research 8(4): 7-10.

59. Pundir S, Saxena S, Aggrawal P (2009) Estimation of age based on tooth cementum annulations using three different microscopic methods. Journal of Forensic Dental Sciences 1: 82-87.

60. Avadhani A, Tupkari J, Khambaty A, Sardar M (2009) Cementum annulations and age determination. Journal of Forensic Dental Sciences 1(2): 73-76.

61. Joshi PS, Chougule MS, Agrawal GP (2010) Comparison of polarizing \& phase contrast microscopy for estimation ofage based on cemental annulations. Indian Journal of Forensic Odontology 3: 17-25.

62. Pinchi V, Forestieri AL, Calvitti M (2007) Thickness of the dental (radicular) cementum: aparameter for estimating age. J Forensic Odontostomatol 25: 1-6.

63. Jankauskas R, Barakauskas S, Bojarun R (2001) Incrementallines of dental cementum in biologicalage estimation. HOMO - Journal of Comparative HumanBiology 52(1): 59-71.

64. Bojarun R, Garmus A, Jankauskas R (2003) Microstructure of dental cementum and individualbiologicalage estimation. Medicina (Kaunas) 39(10): 960-964.

65. Kvaal SI, Solheim T (1995) Incrementallines in human dental cementum in relation to age. Eur J Oral Sci. 103(4): 225-230.

66. Lucas P, W Loh, HS (1986) Are the incrementallines in humancementum laid down annually? Ann. Acad. Med. Singap 15(3): 384-386.

67. Stott GG, Sis RF, Levy BM (1982) Cemental Annulation as an Age Criterion in Forensic Dentistry. Journal of Dental Research 6(6): 814817.

68. Condon K, Charles DK, Cheverud JM, Buikstra JE (1989) Cementum annulation and agedetermination in Homo sapiens. II. Estimates and accuracy. American Journal of Physical Anthropology 71(3): 321-330.

69. Lipsinic FE, Paunovich DG, Houston DG, Robinson SF (1986) Correlation of age and incrementallines in the cementum of humanteeth. Journal of Forensic Sciences 31(3): 982-989.

70. Miller CF, Dove SB, Cottone JA (1988) Failure of use of cemental annulations in teeth to determine the age of humans. Journal of Forensic Sciences 33(1): 137-143.

71. Stein TJ, Corcoran JF (1994) Pararadicular cementumdeposition as a criterion for age estimation in humanbeings. Oral Surgery, Oral Medicine, Oral Pathology 77(3): 266-270. 
This work is licensed under Creative Commons Attribution 4.0 License

DOI: $10.19080 / J F S C I .2017 .03 .555630$
Your next submission with Juniper Publishers will reach you the below assets

- Quality Editorial service

- Swift Peer Review

- Reprints availability

- E-prints Service

- Manuscript Podcast for convenient understanding

- Global attainment for your research

- Manuscript accessibility in different formats ( Pdf, E-pub, Full Text, Audio)

- Unceasing customer service

Track the below URL for one-step submission https://juniperpublishers.com/online-submission. 